\title{
Management of boars for efficient semen production
}

\author{
W. L. Flowers \\ Department of Animal Science, North Carolina State University, Raleigh, \\ NC 27695-7621, USA
}

\begin{abstract}
Consistent production of large quantities of fertile semen is a primary concern of boar management programmes. Common visual tests such as motility are poor indicators of the fertilizing capacity of an ejaculate. Research studies have demonstrated that, in general, if motility is $60 \%$ or greater, there are no relationships among the percentage of motile spermatozoa, in vitro sperm penetration rates, farrowing rates and litter size. Biological and environmental factors that influence the production of total numbers of spermatozoa are either inhibitory or stimulatory. Chronic undernutrition and heat stress inhibit spermatogenesis, while photoperiod and genetic factors are stimulatory. A consistent stimulatory effect of photoperiod does not appear to occur under all environmental conditions. In contrast, selection for increased testis size consistently results in greater sperm production. In addition, libido is decreased by heat stress and undernutrition. However, failure to allow boars to interact socially with other pigs during pubertal development appears to be the most damaging factor. Effective boar management programmes must minimize the occurrence of factors that adversely affect spermatogenesis and simultaneously accentuate those with a stimulatory role.
\end{abstract}

\section{Introduction}

Each time a mating occurs, the boar and sow are generally viewed as contributing equally towards its outcome. Fertilization requires placement of adequate numbers of fertile spermatozoa in the female reproductive tract before ovulation which is closely linked to reproductive processes and behaviour in boars. Establishment of pregnancy involves maintenance of a uterine environment conducive for embryonic and fetal development which is predominantly a biological function of sows. However, when the entire breeding herd is considered, a single boar has a significantly greater impact on efficiency and productivity than an individual sow. This is because a female normally produces two litters per year, whereas a male can sire from 50 to 3000 depending on the type of mating system that is used. Consequently, management strategies for boars tend to influence herd productivity in an exponential fashion and are a major component of reproductive efficiency of swine operations.

Regardless of whether matings are natural or artificial, production of fertile spermatozoa is an absolute requirement for boars and the measure by which their reproductive merit should be evaluated. Therefore, the primary intent of this review is to examine recent developments in terms of our current understanding of biological and environmental factors that influence qualitative and quantitative aspects of sperm production in boars. In addition to spermatogenesis, mating behaviour of boars also has important ramifications with regard to the efficient production of semen especially in breeding programmes using artificial insemination. Consequently, a secondary objective is to consider strategies that have been implemented to enhance the sex drive of boars. The end result should be a summary of relevant reproductive and management data from which informed decisions can be made with regard to managing semen production in boars.

(C) 1997 Journals of Reproduction and Fertility Ltd 


\section{Semen Production}

Consistent production of large numbers of fertile spermatozoa is the ultimate goal of a successful boar management programme. As a result, qualitative and quantitative aspects of semen production have been the primary focus of research for improving boar fertility. For the purposes of this review, quality will refer to fertility, defined as the ability of semen to produce live pigs, and quantity will be defined as the number of spermatozoa produced. It is important to note that there is not an obligatory association between these two aspects of semen production. Thus, each will be considered separately.

\section{Production of fertile semen}

The ability to assess the fertility of semen is a necessary prerequisite for studying the effects of various management strategies designed to improve its quality. In both the scientific and commercial sectors of the swine industry, the most commonly used tests for evaluating sperm quality involve visual estimations of the percentage of motile or morphologically normal spermatozoa (Colenbrander and Kemp, 1990; Woelders, 1991). Furthermore, a common assumption is that ejaculates with a high percentage of motile or morphologically normal sperm cells are of higher quality and more fertile than those with low estimates of the same parameters. In fact, a common practice within commercial boar studs is to adjust the total number of spermatozoa in insemination doses based on sperm motility, or morphology or both factors (Colenbrander et al., 1993). While it is true that, during fertilization, pig spermatozoa rely on their forward motion to move through the cumulus layers and penetrate the zona pellucida (Polge, 1978), the value of using the motility of a raw ejaculate as an indication of its ability to fertilize eggs upon insemination is less clear (See Holt and Medrano, this supplement). In other species, the percentage of motile sperm cells is generally considered to be a poor measure of semen fertility (Linford et al., 1976; Amann, 1988).

Results from a recent study (Flowers and Turner, in press) that examined the relationship between motility and fertility are presented in Table 1. In this experiment, spermatozoa were obtained once a week from 12 mature boars for 26 weeks. Evaluations for motility were conducted on each ejaculate. A portion of each collection was processed for in vitro fertilization, while the remainder was extended and used to inseminate at least five sows. Semen characteristics were divided into ten groups, for example 90 to $100 \%, 80$ to $89 \%$, and treated as an independent variable. Special precautions were taken to ensure that all insemination doses administered to an individual sow during oestrus and the corresponding subsample used in vitro were from the same motility classification. Consequently, the experimental design provided both in vitro and in vivo estimates of fertility for ejaculates exhibiting a wide range of semen motility.

These data provide several important observations concerning the use of the percentage of motile spermatozoa as an estimate of semen fertility in swine. First, motility, at best, can be used to establish the lower limit of acceptability for semen use, but is of little analytical value for ejaculates above this value. This is evident in that sperm penetration rates, farrowing rates and number of pigs born alive were not different among ejaculates estimated to contain more than $60 \%$ motile spermatozoa. In contrast, reproductive performance was reduced in sows inseminated with semen the motility of which was less than $60 \%$. Second, there appear to be individual boars that deviate from this general relationship between motility and fertility. When motility groups were considered in conjunction with individual boar effects, a significant interaction was present. This interaction was attributed to boars whose fertility tended to be low when semen parameters were high or vice versa (Table 2). Finally, inclusion of additional visual criteria such as morphology and acrosome integrity do not improve the predictive value of motility. Adjustments for morphology and acrosome integrity within each motility group did not alter the relationship between the percentage of motile spermatozoa and fertility estimates (data not shown). In summary, it appears that use of the percentage of motile spermatozoa is a qualitative rather than a quantitative measure of semen fertility.

This conclusion should not be surprising. In addition to the mechanical requirements associated with egg penetration, spermatozoa must also undergo biochemical, metabolic and molecular 
Table 1. Relationships among motility, sperm penetration rates, farrowing rates and number of pigs born alive for boar semen

\begin{tabular}{|c|c|c|c|}
\hline $\begin{array}{l}\text { Motility } \\
\text { (\%) }\end{array}$ & $\begin{array}{c}\text { Sperm penetration } \\
\text { rate }^{b}(\%)\end{array}$ & $\begin{array}{l}\text { Farrowing rate } \\
\qquad(\%)\end{array}$ & $\begin{array}{c}\text { Number born } \\
\text { alive }\end{array}$ \\
\hline 94.7 & $\begin{array}{l}89.5^{v} \\
(58)\end{array}$ & $\begin{array}{l}86.9^{v} \\
(460)\end{array}$ & $10.6^{*}$ \\
\hline 82.3 & $\begin{array}{l}81.7^{* w} \\
(55)\end{array}$ & $\begin{array}{l}87.1^{\circ} \\
(330)\end{array}$ & $10.5^{v}$ \\
\hline 76.1 & $\begin{array}{l}84.3^{v, w} \\
(50)\end{array}$ & $\begin{array}{l}84.5^{v} \\
(300)\end{array}$ & $10.5^{v}$ \\
\hline 66.2 & $\begin{array}{l}74.7^{w} \\
(44)\end{array}$ & $\begin{array}{l}86.1^{v} \\
(264)\end{array}$ & $10.1^{v}$ \\
\hline 52.4 & $\begin{array}{l}55.5^{x} \\
(40)\end{array}$ & $\begin{array}{l}72.4^{\mathrm{w}} \\
(201)\end{array}$ & $9.2^{w}$ \\
\hline 44.2 & $\begin{array}{l}34.7 y \\
(28)\end{array}$ & $\begin{array}{l}72.3^{w} \\
(168)\end{array}$ & $9.2^{\mathrm{w}}$ \\
\hline 32.6 & $\begin{array}{l}21.3^{z} \\
(17)\end{array}$ & $\begin{array}{l}51.7^{x} \\
(85)\end{array}$ & $7.8^{x}$ \\
\hline SEM $^{D}$ & 4.8 & 5.8 & 0.3 \\
\hline
\end{tabular}

'Motility is expressed as the average number of motile spermatozoa within the following classes: >90; 80-89; $70-79 ; 60-69 ; 50-59 ; 40-49$; and $30-39$.

Sperm penetration rate is defined as the percentage of eggs that were fertilized. Numbers in parentheses represent the number of ejaculates within a motility category.

Numbers in parentheses represent the number of sows inseminated with semen within a motility category.

¿Standard error of the mean.

swax,yxMeans within the same column with different superscripts are significantly different $(P<0.05)$.

changes before they acquire fertilizational competence. A variety of different tests based on one or more of these events has been or is in the process of being developed (Table 3). For some of these tests there are estimates of their relationship to sperm fertility. The most promising of these attempt to quantify specific aspects of sperm binding to egg membranes or structural changes within sperm membranes or DNA. Obviously, the ideal fertility test for efficient production of semen needs to be proactive, accurate, quick and economical. While many of these new tests appear to fulfil the first two requirements, most require extended analytical periods or sophisticated equipment. As a result, their acceptability and use within the commercial sector, at the present time, remains to be determined.

In addition to spermatozoa, there is an increasing. abundance of evidence that indicates that other components in semen participate in physiological events associated with fertilization (Claus, 1990; Flowers and Esbenshade, 1993; Waberski et al., 1995; Waberski, this supplement). Consequently, it is reasonable to speculate that male fertility may be related, in part, to concentrations of these compounds normally present in semen. At the present time, there is little direct evidence for this speculation in swine. However, consideration of the results from several related experiments provide indirect support for this contention.

In a recent study, DNA fingerprinting techniques were used to determine the paternity of piglets within a litter when several boars were used for breeding (Flowers et al., 1996). The conclusions were that a single boar sired the majority of pigs within a litter $(>80 \%)$ and that this boar was usually the one used for mating 12 or $24 \mathrm{~h}$ after the first detected oestrus. This was expected because previous studies have suggested that the mating that occurs closest to ovulation yields most of the piglets within a litter (Vesseur et al., 1996) and, in this particular herd, the average oestrus-to-ovulation interval was determined by ultrasonography to be $32.6 \pm 4.5 \mathrm{~h}$. However, there was one boar that consistently sired the majority of pigs within a litter when he mated sows at 0 and 12, but not $24, \mathrm{~h}$ after the onset of oestrus. These data are presented in Table 4 and this boar was referred to as being 
Table 2. Relationships among semen motility, sperm penetration rates, farrowing rates and number of pigs born alive for four individual boars

\begin{tabular}{|c|c|c|c|c|}
\hline Boar number & $\begin{array}{l}\text { Motility" } \\
(\%)\end{array}$ & $\begin{array}{c}\text { Sperm penetration } \\
\text { rate }^{\mathrm{b}}(\%)\end{array}$ & $\begin{array}{l}\text { Farrowing } \\
\operatorname{rate}^{c}(\%)\end{array}$ & $\begin{array}{l}\text { Number of pigs } \\
\text { born alive }\end{array}$ \\
\hline 1 & $\begin{array}{l}87.3 \pm 5.3^{x} \\
(26)\end{array}$ & $84.6 \pm 4.8^{x}$ & $\begin{array}{c}83.2 \pm 6.3^{x} \\
(147)\end{array}$ & $10.9 \pm 0.3^{x}$ \\
\hline 2 & $\begin{array}{c}78.3 \pm 6.1^{x} \\
(26)\end{array}$ & $62.3 \pm 5.1^{y}$ & $\begin{array}{c}67.3 \pm 5.8^{y} \\
(133)\end{array}$ & $9.5 \pm 0.4^{y}$ \\
\hline 3 & $\begin{array}{l}55.3 \pm 5.7^{y} \\
(26)\end{array}$ & $81.4 \pm 6.7^{x}$ & $\begin{array}{l}84.1 \pm 6.1^{\times} \\
\quad(130)\end{array}$ & $10.7 \pm 0.3^{x}$ \\
\hline 4 & $\begin{array}{l}51.3 \pm 4.1^{8} \\
(26)\end{array}$ & $52.3 \pm 5.4^{y}$ & $70.3 \pm 4.8^{y}$ & $8.7 \pm 0.3^{y}$ \\
\hline
\end{tabular}

-Motility is the average percentage of motile spermatozoa. Numbers in parentheses indicate the number of ejaculates that were evaluated.

'Sperm penetration rate is the average percentage of eggs that were fertilized.

Numbers in parentheses indicate the number of sows that were mated per boar.

*y Means within the same column with different superscripts are significantly different $(P<0.05)$.

dominant because if he was used for the first or second mating, then he sired the majority of the litter. One of the explanations for this observation was that, for whatever reason, spermatozoa from the dominant boar were retained longer in the female reproductive tract than were those of other males used in the study (designated as non-dominant). Variation among boars in the retention time of their spermatozoa in the female reproductive tract has been described by Mburu et al. (1996) and, in this particular case, was confirmed by subsequent studies as numbers of oviductal spermatozoa from the dominant boar at $24 \mathrm{~h}$ after mating were five times higher than those from non-dominant males (W. L. Flowers, unpublished). An equally feasible explanation that was not explored was that the dominant boar induced an earlier ovulation compared with non-dominant boars. Both retention of spermatozoa in the female reproductive tract and advancement of ovulation have been attributed to seminal plasma (Claus, 1990; Waberski et al., 1995).

Another study was initiated in which heterogeneous inseminations were made by mixing the sperm-rich and seminal plasma fractions of the dominant boar with those of a non-dominant male to determine whether this advantage in sperm retention was a function of spermatozoa or seminal plasma (W. L. Flowers, D. G. McLaren and K. Siggens, unpublished). An outline of the experimental design is shown (Fig. 1). The various combinations of spermatozoa and seminal plasma were used for matings at first detected oestrus, whereas additional boars were used for matings 12 and $24 \mathrm{~h}$ later. Paternity results from these mating treatments are shown in Table 5.

These results indicate that at least part of the dominance effect resides in the seminal plasma. This is evident by the fact that the proportion of piglets sired by the dominant boar was lower when his spermatozoa were mixed with seminal plasma from a non-dominant male, whereas the converse was true with the reciprocal combination, non-dominant semen with dominant seminal plasma. With regards to semen fertility, the relevant finding in this study was that the paternity pattern for piglets was altered by the removal and addition of seminal plasma to spermatozoa. Thus, the relative importance of seminal plasma and its composition deserves consideration when attempting to evaluate the fertility of pig semen. Further credence for this statement is provided by recent studies with cattle. In dairy bulls, the presence of four seminal plasma proteins has been shown to be highly correlated with fertility (Killian et al., 1993), and there is a strong relationship between calving rates and concentrations of heparin-binding proteins in semen of beef bulls (Bellin et al., 1994).

In summary, to produce fertile pig semen, it is necessary to evaluate its fertility accurately. At the present time, most of the visual criteria used to assess semen quality are, at best, crude indicators of its fertilizing properties. Consequently, as new tests with greater accuracy are developed, it will be important to use these for evaluation of semen not only on commercial farms, but also in the 
Table 3. Summary of various measurements used to estimate fertilizing ability of boar spermatozoa

\begin{tabular}{|c|c|c|}
\hline Measurement & Rationale & References \\
\hline $\begin{array}{l}\text { Percoll } \\
\text { gradients }\end{array}$ & $\begin{array}{l}\text { Velocity of spermatozoa is positively } \\
\text { correlated with fertility. Spermatozoa } \\
\text { with increased velocities can be separated } \\
\text { via Percoll gradients }\end{array}$ & Grant et al., 1994 \\
\hline $\begin{array}{l}\text { Fluorescent } \\
\text { stains }\end{array}$ & $\begin{array}{l}\text { Some fluorescent stains (Hoechst } \\
\text { 33258) enter sperm cell if membrane } \\
\text { is damaged and stain only dead cells. } \\
\text { Others (SYBR-14) enter spermatozoa } \\
\text { with a membrane potential and } \\
\text { stain only live cells }\end{array}$ & Johnson et al., 1996 \\
\hline $\begin{array}{l}\text { Sperm chromatin } \\
\text { structure }\end{array}$ & $\begin{array}{l}\text { When subjected to acidic conditions } \\
\text { and stained with metachromatic } \\
\text { dye acridine orange, double-stranded } \\
\text { DNA give a green fluorescence, while } \\
\text { single-stranded DNA (damaged) give } \\
\text { a red fluorescence. Ratio of green to } \\
\text { red spermatozoa is related to fertility } \\
\text {. }\end{array}$ & Evenson et al., 1994 \\
\hline $\begin{array}{l}\text { Sperm plasma } \\
\text { membrane } \\
\text { protein profile }\end{array}$ & $\begin{array}{l}\text { Plasma membrane proteins were } \\
\text { separated and quantified. Three proteins } \\
\text { were positively correlated with sperm } \\
\text { binding to egg membranes ( } r=0.38 \text { to } \\
0.53 \text { ). Two proteins were negatively } \\
\text { correlated with sperm binding ( } r=-0.42 \\
\text { and }-0.37)\end{array}$ & Ash et al., 1994 \\
\hline $\begin{array}{l}\text { Oocyte membrane } \\
\text { binding assay }\end{array}$ & $\begin{array}{l}\text { Fertile spermatozoa bind to egg } \\
\text { membranes. Correlation between egg } \\
\text { binding and fertility in vivo from } \\
\text { heterospermic inseminations was } 0.80\end{array}$ & Berger et al., 1996 \\
\hline $\begin{array}{l}\text { Hemizona } \\
\text { binding assay }\end{array}$ & $\begin{array}{l}\text { Oocytes are bisected and the } \\
\text { number of spermatozoa from different } \\
\text { boars binding to each half of the zona } \\
\text { pellucida are counted. Within a hemizona } \\
\text { pair, increased binding equates to } \\
\text { increased fertility }\end{array}$ & Fazeli et al., 1995 \\
\hline
\end{tabular}

research community as strategies for enhancing male fertility are investigated. Moreover, the composition of seminal plasma may also need to be included in future assessments of semen fertility.

\section{Production of total number of spermatozoa}

In general, management programmes designed to optimize production of the total number of spermatozoa can be divided into two general categories: (i) prevention of detrimental situations and (ii) enhancement of stimulatory influences. In essence, techniques in the first group can be thought of as removal of situations that reduce spermatogenesis, while those in the latter classification are attempts to enhance male gamete formation. Although most of the techniques discussed are dependent upon the age of the boar, there are a few instances where prepubertal males appear to respond in a different way from mature males. When appropriate, these situations will be acknowledged and discussed. 
Table 4. Paternity distribution $(\% \pm$ SEM) of pigs from sows mated to three different boars during oestrus

\begin{tabular}{|c|c|c|c|}
\hline Variable & First sire ${ }^{b}$ & Second sire & Third sire $^{b}$ \\
\hline $\begin{array}{l}\text { Litters in which the dominant } \\
\text { boar was the first sire (10) }\end{array}$ & $89.3 \pm 7.5^{x}$ & $4.5 \pm 1.2^{x}$ & $6.2 \pm 1.3^{x}$ \\
\hline $\begin{array}{l}\text { Litters in which the dominant } \\
\text { boar was the second sire (10) }\end{array}$ & $7.7 \pm 4.3^{y}$ & $88.2 \pm 8.6^{y}$ & $4.3 \pm 1.2^{x}$ \\
\hline $\begin{array}{l}\text { Litters in which the dominant } \\
\text { boar was the third sire (10) }\end{array}$ & $25.4 \pm 7.5^{2}$ & $35.7 \pm 8.2^{2}$ & $38.1 \pm 9.1^{2}$ \\
\hline $\begin{array}{l}\text { Litters in which non-dominant } \\
\text { boars were used as sires }(70)\end{array}$ & $25.7 \pm 3.3^{2}$ & $41.5 \pm 3.7^{2}$ & $32.8 \pm 4.5^{2}$ \\
\hline
\end{tabular}

"Numbers in parentheses indicate number of litters that were evaluated.

bFirst, second and third sire refer to boars that inseminated sows at 0,12 and $24 \mathrm{~h}$ after the onset of oestrus, respectively.

*xM Means with different superscripts within the same column are significantly different $(P<0.05)$.

Prevention of detrimental situations. Nutritional influences on sperm production in mature boars have been reviewed by Colenbrander and Kemp (1990) and Kemp and Verstegen (1991). The general consensus from studies in this area is that prolonged periods of undernutrition reduce the total number of spermatozoa produced. Specifically, the magnitude of protein and energy restrictions reported varied from $25-60 \%$ and $15-67 \%$, respectively, and the restriction period had to be at least $6-8$ weeks before significant differences were observed. The negative effect of undernutrition on spermatogenesis is more pronounced when protein rather than energy is restricted. In fact, Louis and coworkers (1994a) did not observe a reduction in sperm output in boars on a restricted energy diet. However, when dietary levels of only protein or both protein and energy were lowered, the total numbers of spermatozoa were reduced by $18 \%$ and $27 \%$, respectively. Similar studies conducted in prepubertal boars revealed that moderate restrictions in energy and protein during sexual maturation did not affect spermatogenesis (Hacker et al., 1994).

Several different groups have attempted to estimate protein and energy requirements for male reproduction (Kemp et al., 1991; Close and Roberts, 1993). For mature boars (226 kg), 37 MJ of metabolizable energy and $230 \mathrm{~g}$ of crude protein per day appear to be adequate for meeting maintenance, libido and spermatogenic requirements. It is important to note that maintenance requirements for boars are influenced by a variety of environmental factors including health status, ambient temperature and frequency of use. Thus, it is probable that maintenance needs for boars differ among farms. As a result, variability in studies investigating the effect of energy and protein manipulations on reproductive function in boars should be expected.

Perhaps a more relevant point of discussion concerning boar nutrition is the early identification of suboptimal nutritional regimens. Because spermatogenesis requires between 39 and 50 days in boars (Swierstra, 1968), numbers and morphology of spermatozoa would not be expected to reflect nutritional deficiencies immediately. Consequently, a problem could remain undetected for several months. In studies that used chronic restriction regimens, aberrant mating behaviour consistently preceded measurable changes in ejaculate characteristics (Louis et al., 1994a, b). These included extended recognition times, reduced durations of ejaculation and increased frequencies of mating refusals. On the basis of these observations, changes in normal mating behaviour may have potential for use in diagnosing marginal protein and energy deficiencies in boars.

In contrast to the effects of nutrition, exposure to high ambient temperatures has immediate, severe and consistent effects on spermatogenesis (Christenson et al., 1972; Wettemann and Bazer, 1985). These include ejaculation of a large proportion of spermatozoa with morphological abnormalities, fewer 
Table 5. Paternity distribution (\%+SEM) of pigs from sows mated with various combinations of seminal plasma and spermatozoa from dominant and non-dominant boars at the onset of oestrus

\begin{tabular}{|c|c|c|c|}
\hline Treatment & First mating & Second mating & Third mating \\
\hline $\begin{array}{l}\text { Dominant spermatozoa + } \\
\text { dominant seminal plasma (10) }\end{array}$ & $80.3 \pm 6.1^{x}$ & $8.1 \pm 3.2^{x}$ & $11.6 \pm 3.9^{x}$ \\
\hline $\begin{array}{l}\text { Dominant spermatozoa+ } \\
\text { non-dominant seminal } \\
\text { plasma (10) }\end{array}$ & $62.2 \pm 8.3^{y}$ & $17.4 \pm 6.9^{x}$ & $20.4 \pm 5.1^{x}$ \\
\hline $\begin{array}{l}\text { Non-dominant spermatozoa }+ \\
\text { dominant seminal plasma }(10)\end{array}$ & $48.8 \pm 9.1^{y}$ & $30.1 \pm 5.4^{y}$ & $18.7 \pm 6.2^{x}$ \\
\hline $\begin{array}{l}\text { Non-dominant spermatozoa+ } \\
\text { non-dominant seminal } \\
\text { plasma }(10)\end{array}$ & $22.4 \pm 8.3^{z}$ & $44.1 \pm 5.9^{2}$ & $33.5 \pm 6.1^{y}$ \\
\hline
\end{tabular}

Numbers in parentheses indicate number of litters that were evaluated.

-First mating refers to combinations of seminal plasma and spermatozoa from dominant and non-dominant boars that were administered at the onset of oestrus.

Second and third matings were administered at 12 and $24 \mathrm{~h}$ after the onset of oestrus, respectively, by nondominant boars not used for the first mating.

w Means with different superscripts within the same column are significantly different $(P<0.05)$.

spermatozoa and reduced fertility. The minimum exposure time and critical air temperature above which sperm production is impaired have been reported to be $30^{\circ} \mathrm{C}$ (Stone, 1982) and $72 \mathrm{~h}(\mathrm{McNitt}$ and First, 1970), respectively. However, most of the studies conducted to date have used longer periods of exposure (1-4 weeks) and higher temperatures $\left(33-37^{\circ} \mathrm{C}\right)$.

Obviously, an important aspect of efficient semen production is to prevent boars from being exposed to acute periods of heat stress. However, few studies have examined alterations in sperm output from boars exposed for extended periods to temperatures in the upper range of their thermal comfort zone, $26-29^{\circ} \mathrm{C}$. Chronic exposure to temperatures within this range probably occurs routinely during the summer months in mechanically ventilated facilities located in temperate and semi-tropical climates. Field data from seven commercial boar studs in southeastem North Carolina from June through September is shown in Fig. 2. Each stud houses an average of 200 boars and has a weekly production goal of 2000 insemination doses. The average weekly high temperature in these facilities never increased above $29^{\circ} \mathrm{C}$ during the recording period. However, a significant increase in the number of ejaculates that were rejected due to poor quality and a corresponding decrease in the number of insemination doses per ejaculate were observed. It is interesting to note that the downward trend in the number of doses per ejaculate began 5 to 6 weeks after the weekly high temperatures stabilized at $27.5^{\circ} \mathrm{C}$. In acute studies, a lag period of about 2 weeks is commonly observed between the initiation of heat stress and the first indications of abnormal sperm production-(Wettemann et al.,1979). It is possible that these data provide indirect evidence that boars may also be sensitive to chronic periods of moderately high temperatures not normally associated with heat stress conditions. The longer interval between the temperature increase and the first signs of abnormal sperm production may reflect a gradual reduction in the ability of boars to dissipate heat or subtle adjustments in energy partitioning to compensate for the increased demands for maintaining thermal neutrality over an extended period. Regardless of the mechanism, these field data indicate that the idea of chronic heat stress resulting from long periods of exposure to moderately high temperatures merits further investigation.

Enhancement of stimulatory influences. From a physiological perspective, an increase in the total number of spermatozoa produced can be accomplished in one of two ways: either by increasing the number of type A spermatogonia that initiate mitosis at a given time or by increasing the frequency 
Spermatozoa

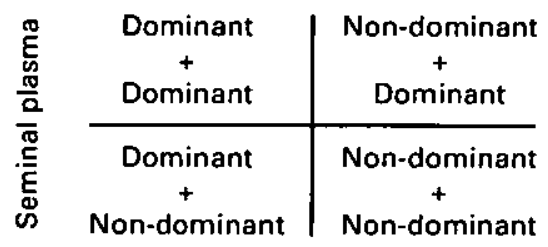

Fig. 1. Experimental treatments consisting of combinations of spermatozoa and seminal plasma. Sperm rich fractions of semen were collected separately from seminal plasma of dominant and non-dominant boars and recombined in a factorial arrangement of treatments as indicated (sperm origin plus seminal plasma origin).

at which this occurs. Both processes are regulated by complex endocrine and paracrine interactions. As a result, most of the management strategies that have attempted to increase sperm production are believed to work through these regulatory pathways.

The effect of photoperiod on sperm production in boars still awaits resolution. Studies investigating the influence of changes in photoperiod on sperm production are equivocal. Mazzari et al. (1968) reported that mature boars exposed to long daylengths exhibited a reduction in total numbers of spermatozoa. In contrast, other studies have reported increased spermatozoa output by increasing light when natural daylength is decreasing or by decreasing light when the natural daylength is increasing (Claus and Weiler, 1985). Brandt and Diekman (1985) did not observe any effects of supplemental lighting on spermatogenesis or concentrations of LH and testosterone. A similar situation is found for the influence of photoperiod on sperm production in prepubertal boars. Additional lighting may hasten the onset of mature testicular function (Hoagland and Diekman, 1982), but does not appear to yield consistent effects on cellular and endocrine aspects of spermatogenesis (Brandt and Diekman, 1985; Minton and Wettemann, 1987).

Thus, it is difficult to formulate definitive recommendations regarding the optimal lighting regimen for spermatogenesis. In addition, failure to measure changes in endocrine activity associated with photoperiodic responses suggests that while in unique situations the light:dark ratio may temporarily influence spermatogenesis, it is probably not a major avenue through which sperm output can be manipulated with consistent results. This statement is supported by the observation that in most males, including wild boars, in which spermatogenesis is linked to photoperiod, there is a corresponding change in the secretion of gonadotrophins and testosterone (Mauget, 1982).

In contrast to the influence of photoperiod, there appears to be a high positive correlation between testis size and sperm production in both prepubertal and mature boars (Rathje et al., 1995). Boars selected for testis size produced $14.6 \times 10^{9}$ more spermatozoa than did randomly selected control males (Huang and Johnson, 1996). On the basis of the industry standard of 3-4 $10^{9}$ spermatozoa per insemination, these values would translate into an additional four to five doses per week. Furthermore, repeatabilities for sperm production traits in this study were reported to be between 0.26 and 0.40 (Huang and Johnson, 1996). Collectively, these data indicate that selection for increased testis size can be used to enhance the reproductive capacity of boars.

As stated earlier, management strategies that enhance sperm production, including selection for increased testicular size probably have a strong endocrine component. This is because most major testicular functions such as establishment of normal populations of Sertoli and Leydig cells and regulation of the timing and frequency of spermatogenic waves are controlled primarily by testosterone, gonadotrophins and growth hormone (Sharpe, 1995). Consequently, hormonal manipulation may offer potential for increasing sperm production. However, for this approach to be practical, identification of critical periods during which brief periods of administration would have long-lasting effects on 

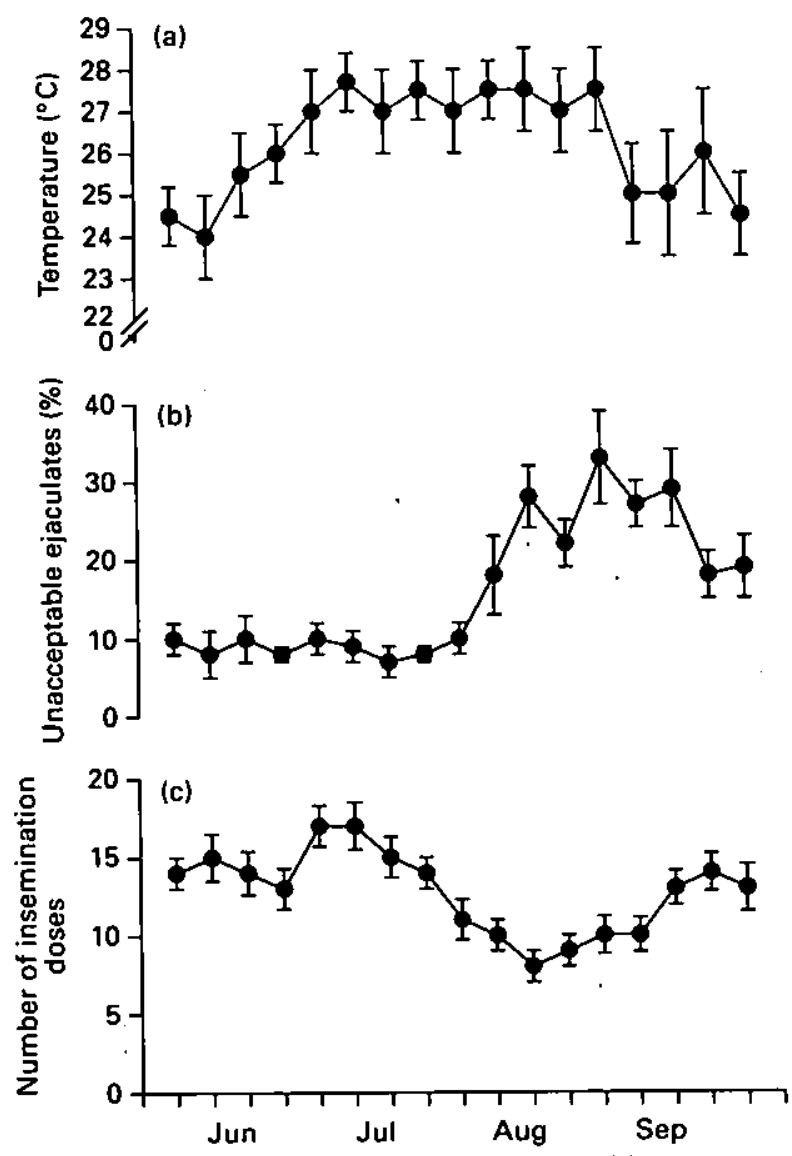

Fig. 2. Mean weekly high ambient temperature (a), percentage of ejaculates rejected for further processing (b) and average number of insemination doses per ejaculate (c) for commercial boar studs in North Carolina between June and September.

spermatogenesis is necessary. At the present time, several studies indicate that this may be possible. Swanlund et al. (1995) administered FSH or growth hormone to boars between 8 and 40 days of age. Growth hormone promoted tubular and Sertoli cell maturation, whereas FSH increased the number of Sertoli cells. In another study, administration of a reversible goitrogen, 6-propyl-2-thiouracil, for the first 8,16 or 24 days after birth increased testis size and daily sperm production in adult rats (Cooke $e t$ al., 1992). Obviously, considerably more research is needed to determine whether sperm production in boars can be manipulated effectively via hormonal regimens. However, it is important to remember that the use of exogenous gonadotrophins and prostaglandins at specific times during the production cycle has proved to be beneficial for enhancing reproductive efficiency in female swine.

\section{Libido and Mating Behaviour}

In boar management programmes, maintenance of high levels of libido probably deserves equal consideration as increasing sperm output. It could be argued that production of large amounts of fertile semen is of limited value if the desire to mate is not present. Unfortunately, our current understanding of factors affecting the sex drive of boars is more anecdotal than scientific. This may be 
Table 6. Summary of management situations that influence libido and mating behaviour in boars

\begin{tabular}{|c|c|c|c|}
\hline Situation & Age & Effect & Reference \\
\hline Protein restriction & Mature (> 1 year) & $\begin{array}{l}\text { Increased time to } \\
\text { initiate ejaculation } \\
\text { Decreased duration } \\
\text { of ejaculation }\end{array}$ & $\begin{array}{l}\text { Louis et al., } \\
1994 a, b\end{array}$ \\
\hline Ad libitum feeding & $\begin{array}{l}\text { Prepubertal (between } \\
1 \text { and } 8 \text { months of age) }\end{array}$ & $\begin{array}{l}\text { Decreased chomping } \\
\text { and salivation }\end{array}$ & $\begin{array}{l}\text { Hacker et al., } \\
1994\end{array}$ \\
\hline Individual housing & $\begin{array}{l}\text { Prepubertal (between } \\
1 \text { and } 8 \text { months of age) }\end{array}$ & $\begin{array}{l}\text { Increased recognition } \\
\text { time } \\
\text { Increased incorrect } \\
\text { mounts } \\
\text { Decreased mating } \\
\text { scores }\end{array}$ & $\begin{array}{l}\text { Hemsworth } \\
\text { et al., } 1977 \\
\text { Hacker et al., } \\
1994\end{array}$ \\
\hline High temperatures & Mature ( $>1$ year) & $\begin{array}{l}\text { Decreased mounting } \\
\text { attempts } \\
\text { Decreased duration } \\
\text { of ejaculation }\end{array}$ & $\begin{array}{c}\text { Christenson } \\
\text { et al., } 1972 \\
\text { Claus and } \\
\text { Weiler, } 1985\end{array}$ \\
\hline $\begin{array}{l}\text { Decreased light } \\
\text { when natural } \\
\text { photoperiod is } \\
\text { increasing }\end{array}$ & Mature (>1 year) & $\begin{array}{l}\text { Decreased reaction } \\
\text { time }\end{array}$ & $\begin{array}{l}\text { Claus and } \\
\text { Weiler, } 1985\end{array}$ \\
\hline Supplemental light & $\begin{array}{l}\text { Prepubertal (between } \\
15 \text { and } 32 \text { weeks of age) }\end{array}$ & Increased libido scores & $\begin{array}{l}\text { Berger } \text { et al., } \\
\text { 1980; } \\
\text { Hoagland and } \\
\text { Diekman, } \\
1982\end{array}$ \\
\hline
\end{tabular}

because behavioural responses are often more variable and less repeatable than physiological responses.

The results of several studies that have examined the influence of various aspects of the production environment of sexual behaviour in boars are summarized (Table 6). Collectively, these data indicate that isolation during pubertal development, chronic nutritional restriction and exposure to high ambient temperatures reduce libido or the performance of male mating behaviours. The effect of isolation during pubertal development appears to be related to the lack of experience in practising or participating in mounting behaviours during adolescence (Hemsworth et al., 1977), while nutritional and environmental effects are related, at least in part, to a reduction in the endocrine activity of the hypothalamo-hypophyseal-testis axis (Wetteman and Desjardins, 1979; Louis et al., 1994b). It is interesting to note that most of the detrimental influences outlined in Table 6 are chronic as opposed to acute deficiencies in the production environment.

Reports of strategies with acute effects on libido in boars are scarce. Intuitively, administration of testosterone would seem to be a logical approach. Although testosterone does produce short-term improvements in sex drive and mounting activity, it also results in a suppression in spermatogenesis if used for extended periods owing to its negative effect on LH secretion (Bishop et al., 1992). Prostaglandins are involved in a variety of male sexual behaviours (Miesel and Sacks, 1994) and, thus, are commonly administered in an attempt to stimulate sexual interest and mounting behaviour in boars. Definitive studies are still needed to establish the effectiveness of this practice and any repercussions it may have on sperm production. 


\section{Conclusion}

Most visual tests commonly used to evaluate semen quality in boars are poor indicators of fertility. As a result, our current understanding of the manner in which nutrition, environment and other management parameters affect sperm fertility from studies that have used these tests may not be as accurate as once believed. Consequently, as tests more closely linked to the fertilization process are developed, it may be necessary to revisit some of these areas of research. In addition, it appears that most of the situations that are detrimental to sperm production and male sexual behaviour, with the obvious exception of exposure to acute heat stress conditions, result from chronic or long-term inadequacies in the production environment. Given the relatively short period during which boars are normally used within operations for breeding, 7 months to 1.5 years, management of boars during pubertal development should be given as much, if not more, consideration as the manner in which they are handled as adults.

\section{References}

Amann RP (1988) Relationships between computerized evaluations of spermatozoal motion and competitive fertility index Procedings of the 11th International Congress on Animal Reproduction and Artificial Insemination Dublin pp 38-44

Ash KL, Berger T, Homer CM and Famula TR (1994) Boar sperm plasma membrane protein profile: correlation with the zona-free hamster ova assay Theriogenology 42 1217-1226

Bellin ME, Hawkins HE and Ax RL (1994) Fertility of range beef bulls grouped according to presence or absence of heparin-binding proteins in sperm membranes and seminal fluid Journal of Animal Science 74 173-182

Berger T, Mahone JP, Syoboda GS, Metz KW and Clegg ED (1980) Sexual maturation of boars and growth of swine exposed to extended photoperiod during decreasing natural photoperiod Journal of Amimal Science 51 672-678

Bergez T, Anderson DL and Penedo MCT (1996) Porcine sperm fertilizing potential in relationship to sperm functional capacities Animal Reproduction Science 44 231-239

Bishop DK, Wettemann RP and Maxwell CV (1992) Prepuberal testosterone treatment and testes development, spermatogenesis and sexual behavior of boars. In Animal Science Research Report pp 383-388 Agricultural Experiment Station, Oklahoma State University, Stillwater, OK

Brandt KE and Diekman MA (1985) lnfluence of supplemental lighting on serum LH, testosterone and semen quality in prepubertal and postpubertal boars Animal Reproduction Science 8 287-294

Christenson RK, Teague HS, Grifo AP, Jr and Roller WL (1972) The effect of high environmental temperature on the boar. In Ohio Swine Research and Information Report pp 19-23 Ohio Agricultural Research and Development Center, Wooster, Ohio

Claus R (1990) Physiological role of seminal components in the reproductive tract of the female pig Journal of Repraduction and Fertility Supplement 40 117-131

Claus $R$ and Weiler $U$ (1985) Influence of light and photoperiodicity on pig prolificacy Joumal of Reproduction and Fertility Supplement 33 185-197

Close WH and Roberts FG (1993) Nutrition of the working boar. In Recent Developments in Pig Nutrition 2 pp 347-368 Eds DJA Cole, W Haresign and PC Garnsworthy. Nottingham University Press, Nottingham

Colenbrander B and Kemp B (1990) Factors influencing semen quality in pigs Journal of Reproduction and Fertility Supplement 40 105-115
Colenbrander B, Feitsma $H$ and Grooten HJ (1993) Optimizing semen production for artificial insemination in swine Journal of Reproduction and Fertility Supplement 48 207-215

Cooke PS, Porcelli J and Hess RA (1992) Induction of increased testis growth and sperm production in adult rats by neonatal administration of the goitrogen propylthiouracil (PTU): the critical period Biology of Reproduction $46146-$ 154

Evenson DP, Thompson L and Jost L (1994) Flow cytometric evaluation of boar semen by the sperm chromatin structure assay as related to cryopreservation and fertility Theriogenology 41 637-651

Fazeli AR, Holt C, Steenweg W, Bevers MM, Holt WV and Colenbrander B (1995) Development of a sperm hemizona binding assay for boar semen Theriogenology 44 17-27

Flowers WL and Esbenshade KL (1993) Optimizing management of natural and artificial matings in swine lourmal of Reproduction and Fertility Supplement 48 217-228

Flowers WL and Turner ZA Relationships among motility, morphology and fertility estimates for boar semen Journal of Animal Science (in press)

Flowers WL, Siggens K and McLaren DG (1996) Paternity of pigs from sows bred with combinations of natural service (NS) and Al Journal of Animal Science 74 (Supplement 1) P 223 (Abstract)

Grant SA, Long SE and Parkinson TJ (1994) Fertilizability and structural properties of boar spermatozoa prepared by Percoll gradient centrifugation Journal of Reproduction and Fertility $100477-483$

Hacker RR, Du Z and D'arcy CJ (1994) Influence of penning type and feeding level on sexual behavior and feet and leg soundness in boars Journal of Animal Science 72 2531-2537

Hemsworth PE, Beilharz RG and Galloway DB (1977) Influence of social conditions during rearing on the sexual behaviour of the domestic boar Animal Production 27 201-212

Hoagland TA and Diekman MA (1982) Influence of supplemental lighting during increasing daylength on libido and reproductive hormones in prepubertal boars journal of Animal Science 55 1483-1489

Huang Y-T and Johnson RK (1996) Effect of selection for size of testes in boars on semen and testis traits Journal of Animal Science 74 750-760

Johnson LA, Maxwell WMC, Dobrinsky JR and Welch GR (1996) Staining sperm for viability assessment Reproduction in Domestic Animals 31 37-47 
Kemp B and Verstegen MWA (1991) Nutrition and sperm production Reproduction in Domestic Animals Supplement 1 287-298

Kemp B, Bakker GCM, den Hartog LA and Verstegen MWA (1991) The effect of semen collection frequency and food intake on semen production in breeding boars Animal Production 52 355-364

Killian GJ, Chapman DA and Rogowski LA (1993) Fertility-associated proteins in holstein bull seminal plasma Biology of Reproduction 49 1202-1207

Linford E, Glover FA, Bishop C and Stewart DL (1976) The relationship between semen evaluation methods and fertility in the bull joumal of Reproduction and Fertility 47 283-291

Louis GF, Lewis AJ, Weldon WC, Ermer PM, Miller PS, Kittock RJ and Stroup WW (1994a) The effect of energy and protein intakes on boar libido, semen characteristics, and plasma -hormone concentrations Journal of Animal Science 72 2051-2060

Louis GF, Lewis AJ, Weldon WC, Miller PS, Kittock RJ and Stroup WW (1994b) The effect of protein intake on boar libido, semen characteristics, and plasma hormone concentrations Joumal of Anirial Science 72 2038-2050

McNitt Jl and First NL (1970) Effect of 72-hour heat stress on semen quality in boars international journal of Biometrics 14 $373-380$

Mauget R (1982) Seasonality of reproduction in the wild boar. In Control of Pig Reproduction pp 509-526 Eds DJA Cole and GR Foxcroft. Butterworth Scientific, London

Mazzari G, du Mesnil du Buisson F and Ortavant R (1968) Action de la temperature et de la lumiere sur la spermatogenese, la production et le pouvoir lecondant de sperme chez le verrat Proceedings of the 6th International Congress on Animal Reproduction and Artificial insemination 1305-308

Mburu JN, Einarsson S, Lundeheim N and Rodriquez-Martinez H (1996) Distribution, number and membrane integrity of spermatozoa in the pig oviduct in relation to spontaneous ovulation Animal Reproduction Science 45 109-121

Meisel RL and Sachs BD (1993) The physiology of male sexual behavior. In The Physiology of Reproduction Vol. 2 pp 3-106 Eds E Knobil and JD Neill. Raven Press, New York

Minton JE and Wettemann RP (1987) Growth, testicular and endocrine function of boars exposed to 8,16 or 24 hours of light daily before puberty Animal Reproduction Science 14 239-244
Polge C (1978) Fertilization in the pig and horse Joumal of Reproduction and Fertility $54461-474$

Rathje TA, Johnson RK and Lunstra DD (1995) Sperm production in boars after nine generations of selection for increased weight of testis joumal of Animal Science 73 2177-2188

Sharpe RM (1993) Regulation of spermatogenesis. In The Physiology of Reproduction Vol. 1 pp 1363-1434 Eds E Knobil and JD Neill. Raven Press, New York

Stone BA (1982) Heat induced infertility of boars: the inter-relationship between depressed sperm output and fertility and an estimation of the critical air temperature above which sperm output is impaired Animal Reproduction Science 4 283-299

Swanlund DJ, N'Diaye MR, Loseth KJ, Pryor JL and Crabo BG (1995) Diverse testicular responses to exogenous growth hormone and follicle-stimulating hormone in prepubertal boars Biology of Reproduction 53 749-757

Swiestra EE (1968) Cytology and duration of the cycle of the seminiferous epithelium of the boar. Duration of the spermatozoa transit through the epididymis Anatomical Record 161 171-186

Vesseur PC, Kemp B and den Hartog LA (1996) Factors influencing the proportion of offspring from a second insemination in sows Animal Reproduction Science 41 255-265

Waberski D, Sudhoff H, Hahn T, Jungblut PW, Kallweit E, Calvete JJ, Ensslin M, Hoppen H-O, Wintergalen N, Weitze KF and Toper-Peterson $E$ (1995) Advanced ovulation in gilts by the intrauterine application of a low molecular mass pronasesensitive fraction of boar seminal plasma joumal of Reproduction and Fertility 105 247-252

Wettemann RP and Bazer FW (1985) Influence of environmental temperature on prolificacy of pigs Joumal of Reproduction and Fertility Stuplement 33 199-208

Wettemann RP and Desjardins C (1979) Testicular function in boars exposed to elevated ambient temperature Biology of Reproduction 20 235-241

Wettemann RP, Wells ME and Johnson RK (1979) Reproductive characteristics of boars during and after exposure to increased ambient temperature Journal of Animal Science 49 1501-1505

Woelders H (1991) Overview of in vitro methods for evaluation of semen quality Reproduction in Domestic Animals Supplemtent 1 145-164 